\title{
Karakterisasi Sambungan Friction Stir Spot Welding pada Plat Aluminium 5083
}

(The Characterization of Aluminum 5083 Plate Friction Stir Spot Welded Joint)

\author{
ARIS Widyo NugroHo, FAJAR HARI PURNOMO, MUHAMMAD BUdi NUR RAHMAN
}

\begin{abstract}
ABSTRAK
Karakterisasi sambungan las titik aduk pelat Alumunium 5083 telah dilakukan untuk mengetahui pengaruh waktu diam dan putaran pahat terhadap sambungan. Plat Aluminium 5083 dipotong menjadi benda uji dengan dimensi 100 x 30 x 3 mm. Sambungan putaran diterapkan untuk mengelas spesimen sesuai dengan standar AWS D8.9-97. Alat dengan diameter bahu $20 \mathrm{~mm}$ dan pin tirus disiapkan. Proses Friction strir welding (FSSW) dilakukan dengan menggunakan parameter dwell-time 5, 10 dan $15 \mathrm{~s}$ dengan kecepatan putar masing-masing 1500 dan $2280 \mathrm{rpm}$. Temperatur pelat di dekat pin selama proses pengelasan diukur menggunakan termokopel tipe $\mathrm{K}$. Morfologi dan struktur mikro sendi diamati menggunakan mikroskop optik. Kekerasan dan kapasitas beban tarik dari sambungan juga dievaluasi. Hasil penelitian menunjukkan bahwa parameter kecepatan rotasi dominan mempengaruhi kualitas sambungan. Daya dukung tarik yang lebih tinggi ditemukan pada kecepatan putar yang lebih tinggi pada setiap dwell-time yang mencapai maksimum 3105,4 N. Semua spesimen menunjukkan kegagalan pull out nugget akibat terjadinya beban geser yang mendominasi penyebab kegagalan.
\end{abstract}

Kata kunci: friction stir spot welding, dwell-time, kecepatan rotasi tool.

\section{ABSTRACT}

The characterization of the aluminum 5083 plate friction stir spot welded joints has been carried out in order to determine the effect of dwell-time and tool rotation on the joint. An Aluminum 5083 plate was cut into specimens with the dimension of $100 \times 30$ $x 3 \mathrm{~mm}$. A lap joint was applied to weld the specimen in accordance with the AWS D8.9-97 standard. A tool with a shoulder diameter of $20 \mathrm{~mm}$ and the tapered pin was prepared. The friction strir welding (FSSW) process was undergone using the dwelltime parameters of 5,10 , and $15 \mathrm{~s}$ with rotational speeds of 1500 and $2280 \mathrm{rpm}$ of each. Temperatures of the plate near the pin during the welding procces were measured using $K$ type thermocouple. Morphology and microstructure of the joint were observed using an optical microscope. Hardness and the tensile bear load capacity of the joint were also evaluated. The results show that a rotational speed parameter predominantly affects the quality of the joint. A higher stensile bearing load capacity was found at a higher rotational speed on each dwell-time reaching a maximum of 3105,4 N. All spesimens show a nugget pull-out failure due to an occuring of shear load which dominates causing failure. .

Keywords: friction stir spot welding; dwell-time; rotational tool speed.

\section{Pendahuluan}

Aluminium merupakan logam yang sering digunakan pada fasilitas manufaktur dan otomotif. Bahan logam tersebut memiliki ketahanan terhadap korosi yang baik dan mempunyai sifat weldability (mampu las) yang berbeda menurut paduannya, serta termasuk salah satu logam dengan sifat penghantar listrik yang baik. Aluminium merupakan material yang lebih ringan dari baja. Dengan bobot yang ringan sangat dirasa mampu meningkatkan nilai ekonomi bahan bakar serta kinerja kendaraan karena pengurangan berat pada bodi kendaraan 
merupakan sesuatu yang berpengaruh signifikan. Penggunaan logam aluminium lebih luas lagi ditemukan pada kedirgantaraan, transportasi, perkapalan dan lain- lain, karena keunggulan aluminium dari pada logam lain.

Penyambungan-titik alumunium dapat dilakukan dengan metode pengelasan. Metode penyambungan titik yang biasanya digunakan pada industri manufaktur saat ini yaitu teknik Resistance spot welding (RSW) dan keling. Kerugian dari metode ini termasuk konsumsi energi yang tinggi dan penggunaan bahan habis pakai. Selain itu, disebabkan sifat fisik paduan aluminium maka diperlukan daya listrik yang tinggi serta tingkat cacat di area las lebih tinggi dibandingkan pada pengelasan lembaran baja (Mahoney dan Mishra, 2007). Kelemahan RSW yang lain jika digunakan pada paduan aluminium yaitu porositas dan retakan (crack). Solusi yang bisa dipakai yaitu melakukan pengelasan dengan suhu dibawah titik cair logam induk (solid state welding). Friction Stir Spot Welding (FSSW) termasuk dalam teknik solid state serta Non-Consumable Welding dengan tidak adanya filler dan tidak diperlukan instalisasi gas. Memanfaatkan energi panas yang dihasilkan dari proses gesekan antara tool dengan base metal yang di sambung, metode semacam ini menggunakan teknik termomekanik.

Beberapa penelitian berkaitan dengan FSSW sudah pernah dilakukan diantaranya dilakukan oleh Bilici dan Yukler (2012) yang melakukan pengamatan pengaruh tool geometry dan parameter proses terhadap struktur makro serta kekuatan statis nya pada pengelasan lembaran polyethelene. Al-Khateeb dan Takhakh (2011) dalam investigasinya melakukan upaya untuk memahami pengaruh diameter shoulder tool pada sifat mekanik dari sambungan dengan menggunakan empat variasi diameter 10, 13, 16 dan $19 \mathrm{~mm}$. Badarinarayan, dkk, (2009) melakukan penelitian tentang FSSW pada paduan aluminium 5083 dengan ketebalan berbeda masing-masing 1,64 dan 1,24 mm, serta shoulder tool berdiameter $12 \mathrm{~mm}$ dengan pin silinder konvensional dan pin segitiga. Baskoro, dkk (2019) dan Baskoro dkk (2020) yang melakukan investigasi pengaruh parameter pengelasan FSSW pada plat dengan ketebalan $0.42 \mathrm{~mm}$ menyatakan bahwa $d w e l l$ time diamter tool dan plunge depth merupakan parameter penting yang berpengaruh pada kapasitas beban tarik geser sambungan AA1100.

Berdasarkan paparan diatas, penelitian terhadap metode FSSW pada material aluminium baru dilakukan sebatas pada ketebalan di bawah 2 $\mathrm{mm}$. Sedangkan diameter shoulder yang digunakan dibawah $20 \mathrm{~mm}$. Karakterisasi hasil sambungan FSSW pada pelat aluminium dengan tebal di atas $2 \mathrm{~mm}$ masih sangat sedikit referensi. Oleh karena itu, penelitian ini menggunakan pelat aluminium dengan tebal 3 $\mathrm{mm}$ serta memperbesar diameter shoulder 20 $\mathrm{mm}$.

\section{Metode PENELITIAN}

Material pelat aluminium 5083 dengan dimensi $100 \times 30 \times 3 \mathrm{~mm}$. Sambungan tumpang tindih (lap joint) diproduksi dengan area yang tumpang tindih sepanjang $30 \mathrm{~mm}$ sesuai standar AWS D8.9-97 dan pada bagian tengahnya dilakukan proses FSSW. Geometri tool yang digunakan berbentuk pin silinder tirus dengan tinggi $5 \mathrm{~mm}$, diameter atas $6 \mathrm{~mm}$ dan bawah 3 $\mathrm{mm}$ serta dengan diameter shoulder $20 \mathrm{~mm}$. Proses FSSW dilakukan dengan variasi $d w e l l-$ time 5, 10, dan $15 \mathrm{~s}$, menggunakan dua variasi kecepatan rotasi tool 1500 dan $2280 \mathrm{rpm}$ dengan putaran tool searah jarum jam. Pengamatan data suhu selama proses pengelasan digunakan dua buah termokopel tipe K. Termokopel 1 ditanam di garis tengah las pada pelat aluminium bagian atas sedalam 7 $\mathrm{mm}$. Sedangkan pada pelat aluminium bagian bawah ditanam termokopel 2 sedalam $12 \mathrm{~mm}$ dengan jarak $6 \mathrm{~mm}$ dari garis tengah las, seperti ditunjukkan Gambar 1. 

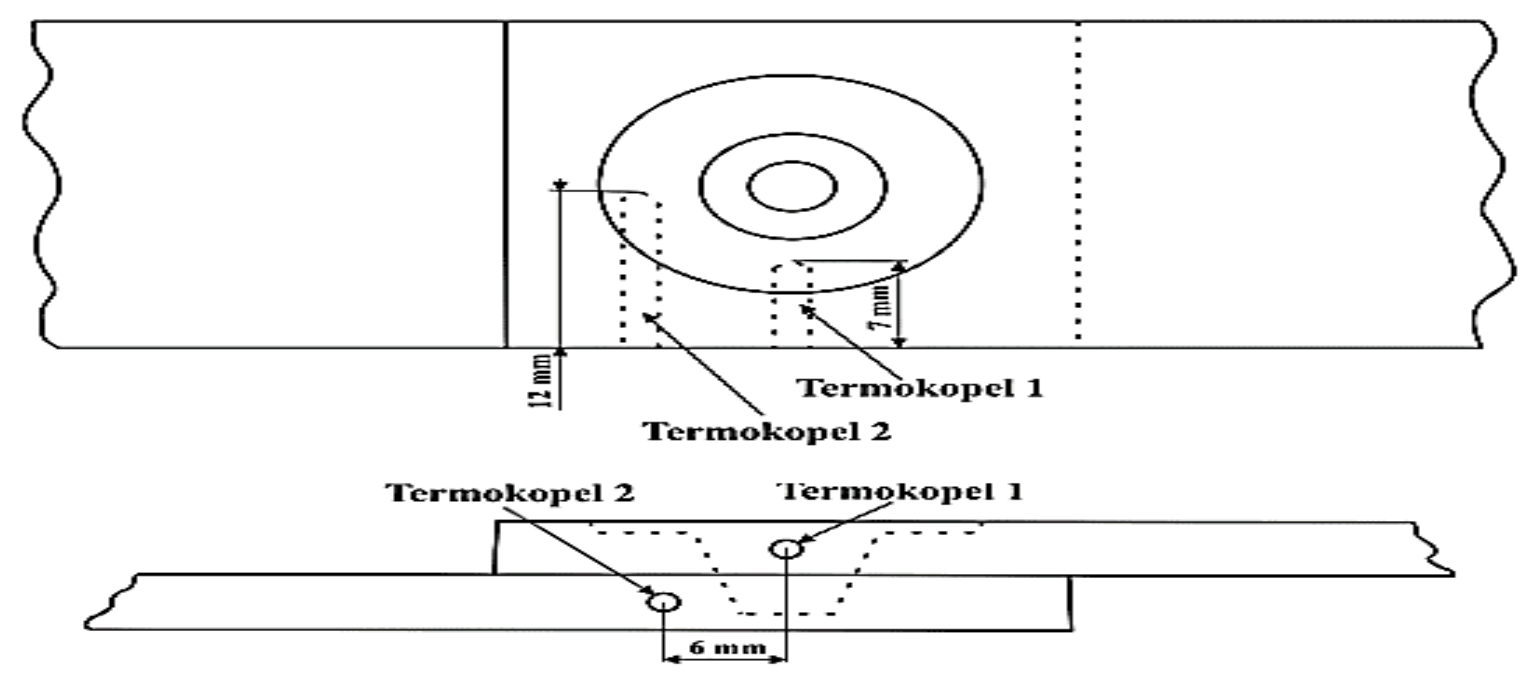

Gambar 1. Skema Pemasangan Termokopel

Spesimen pengamatan strukturmikro dikerjakan dengan pengamplasan dan pemolesan menggunakan autosol serta dilakukan pengetsaan mengacu pada standar standar ASTM E 407-07. Strukturmakro dari penampang litang sambungan diamati menggunakan Olympus SZ-LW61 T3. Sedangkan pengamatan pada strukturmikro menggunakan Olympus U- MSSP4I. Pengujian kekerasan dilakukan menggunakan Mitutoyo HM-100 micro vickers hardness tester, dengan beban penekanan sebesar 500 gf dan lama penekanan $10 \mathrm{~s}$. Pengujian tarik dari sambungan digunakan mesin Universal Testing Machine (UTM) HUNG TA dengan model HT-9501.

\section{HASIL DAN PEMBAHASAN}

Hasil pengelasan dengan kecepatan rotasi tool 1500 dan $2280 \mathrm{rpm}$ dengan tiga variasi DT ditunjukkan oleh Gambar 2. Hasil pengelasan pada masing-masing spesimen menunjukkan adanya weld flash serta meninggalkan lubang kunci (key hole) yang merupakan ciri khas dari metode FSSW. Pengelasan dengan DT yang lebih lama menghasilkan kontur permukaan yang lebih halus jika dibandingkan dengan dua variasi DT lainnya seperti pada variasi rotasi $1500 \mathrm{rpm}$.

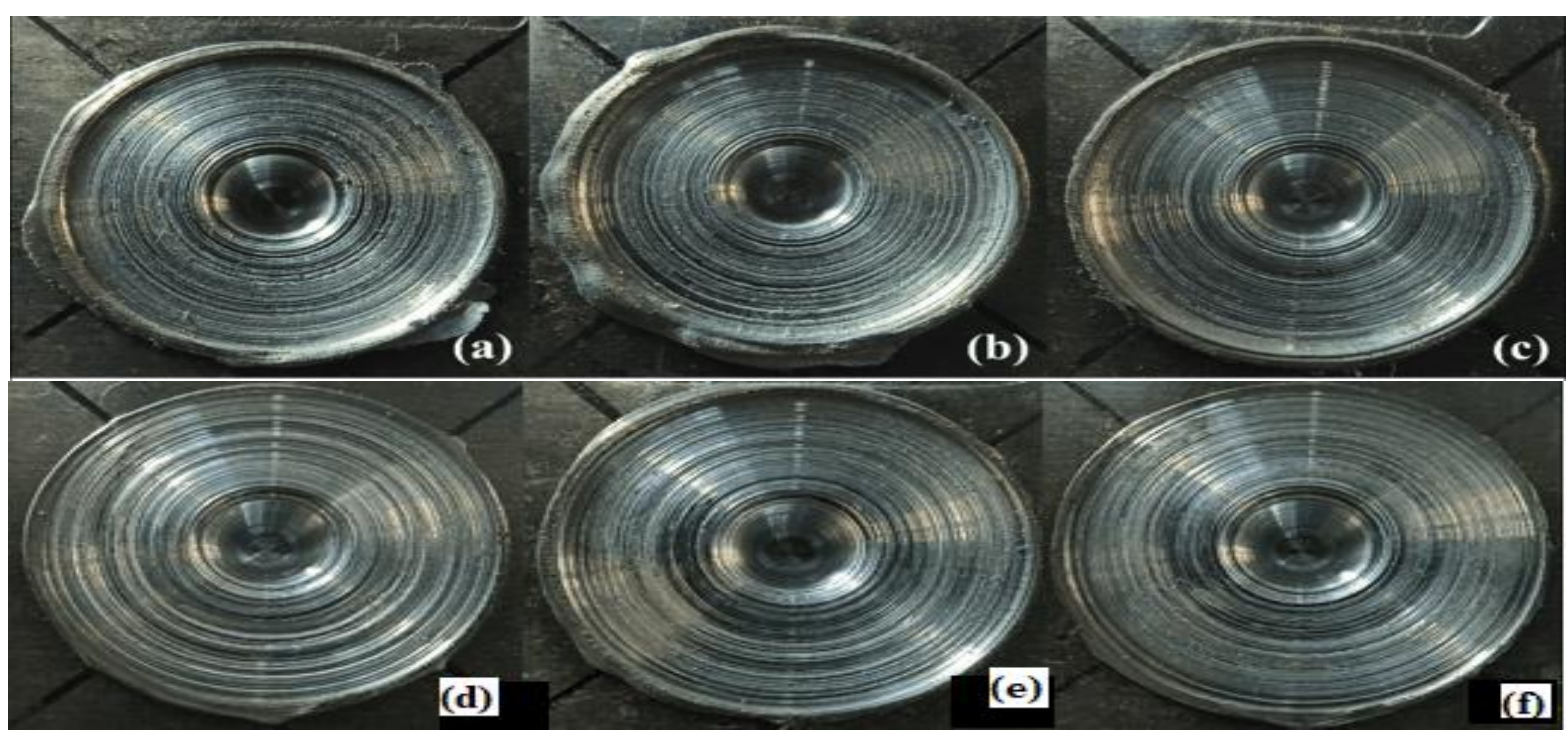

Gambar 2. Hasil Pengelasan dengan Kecepatan Putar 1500 dan DT 5, 10, 15 s (a, b, c) dan Kecepatan Putar 2250 dan DT 5, 10 dan 15 s (d, e dan f) 
Li, dkk (2019) menyatakan bahwa peningkatan DT mengarah ke gaya terjun dan torsi yang lebih rendah karena tingkat pelunakan logam yang lebih tinggi. Saat suhu lebih tinggi, bahan melunak dan mulai mengalir di sekitar shoulder, yang mengarah ke penurunan resistensi gesekan antara shoulder tool dan logam. Penurunan resistensi gesekan tersebut menghasilkan permukaan yang lebih halus dibandingkan dengan DT yang lebih kecil.
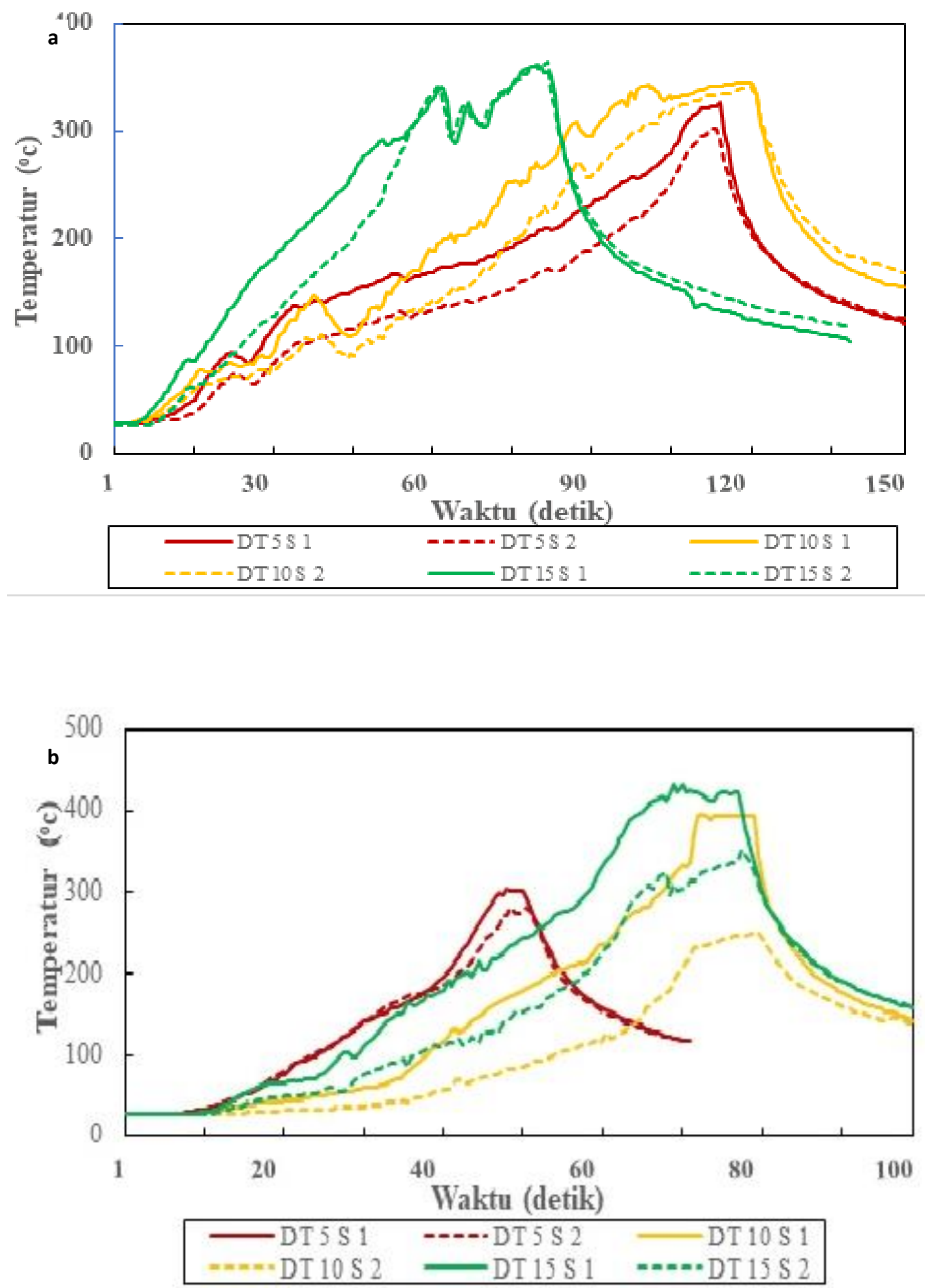

Gambar 3. Siklus Temperatur Proses Pengelasan FSSW (a) 1500 Rpm; (b) 2280 Rpm 
Hasil pengukuran temperatur pengelasan secara umum terbagi menjadi tiga daerah yaitu: (a) daerah welding penetration yang ditunjukkan dengan kenaikan suhu yang cepat dan kontinyu (b) daerah DT yang ditandai dengan pencapaian suhu maksimum dan cenderung konstan sesuai dengan waktu proses, dan (c) daerah retraction yang digambarkan dengan penurunan suhu dengan cepat (Gambar 3). Temperatur pengelasan dengan kecepatan rotasi $1500 \mathrm{rpm}$, mengalami kenaikan dari DT $5 \mathrm{~s}$ ke DT 10 dan $15 \mathrm{~s}$. Temperatur pengelasan tertinggi terjadi pada DT $15 \mathrm{~s}$ dan terendah terjadi pada DT $5 \mathrm{~s}$ baik pada termokopel 1 atau pun termokopelc2. Angka temperatur tertinggi pada termokopel 1 sebesar $360,43^{\circ} \mathrm{C}$ dan terendah dengan angka $326,85^{\circ} \mathrm{C}$. Sedangkan temperatur tertinggi pada termokopel $2364,50^{\circ} \mathrm{C}$ dan terendah $302,72^{\circ} \mathrm{C}$. Tren berbeda terjadi pada variasi DT $15 \mathrm{~s}$ dimana puncak suhu termokopel 2 lebih tinggi dibanding dengan termokopel 1 . Hal tersebut dapat terjadi dimungkinkan karena efek getaran serta tekanan dari proses pengelasan yang membuat ujung sensor termokopel 1 tidak berada di posisi awal. Kondisi tersebut berakibat letak sensor termokopel menjauh dari titik las. Hasil pengukuran temperatur pengelasan dengan kecepatan rotasi $2280 \mathrm{rpm}$, dari DT $5 \mathrm{~s}$ ke DT 10 dan $15 \mathrm{~s}$ mengalami kenaikan temperatur baik pada termokopel 1 maupun termokopel 2 di masing-masing variasi DT. Hasil pembacaan termokopel 1 menunjukkan temperatur tertinggi terjadi pada DT $15 \mathrm{~s}$ sebesar $433,18^{\circ} \mathrm{C}$, sedangkan temperatur terendah $304,46^{\circ} \mathrm{C}$ terjadi pada DT 5 s. Hal berbeda terjadi pada pembacaan termokopel 2 dimana temperatur terendah terbaca $249,91^{\circ} \mathrm{C}$ pada DT $10 \mathrm{~s}$, sedangkan temperatur tertinggi $352,54^{\circ} \mathrm{C}$ pada DT $15 \mathrm{~s}$. Hal tersebut dimungkinkan terjadi karena ujung sensor termokopel 2 tidak pada posisi awalnya disebabkan getaran atau pun pergeseran material pelat proses pengelasan dilakukan.
Dalam FSSW, panas dihasilkan oleh gesekan dan deformasi plastis, yang dipengaruhi oleh parameter lasan, konduktivitas termal benda kerja, dan geometri tool. Semua pengukuran, umumnya hasil suhu untuk titik termokopel 1 lebih tinggi dari titik termokopel 2. Hal ini dapat dikaitkan dengan posisi titik-titik tersebut. Posisi titik termokopel 1 berada di antara shoulder dan pin tool, mengakibatkan suhu lebih tinggi yang disuplai dari dua sisi hasil gesekan permukaan shoulder dan pin tool dengan material. Hal tersebut seperti yang ditemukan oleh Mahoney \& Mishra, (2007), pada eksperimental awal mereka, menunjukkan bahwa sebagian besar pembangkitan panas terjadi pada antarmuka shoulder dan benda kerja. Aliran material yang terbentuk terkait dengan panas yang dihasilkan serta sifat material. DT yang lebih lama mengakibatkan deformasi pada sambungan meningkat karena pengadukan yang lebih banyak. Deformasi ini bersifat plastis yang menyebabkan panas, akibatnya temperatur las juga meningkat. Hasil pengamatan data suhu pada penelitian ini sama halnya dengan yang ditemukan oleh $\mathrm{Li}$, dkk (2019) bahwa peningkatan DT mengarah ke suhu puncak yang lebih tinggi,

Penampakan dari penampang sambungan hasil pengelasan FSSW ditunjukkan oleh Gambar 4. Semua kondisi pengelasan yang diamati, sambungan bebas cacat mayor, namun terjadi sedikit rongga kecil pada bagian atas daerah las yang mengarah ke bawah. Rongga tersebut tercipta karena ketika pin menyentuh bagian atas material pelat, material tersebut terekstrusi ke atas. Selanjutnya, hasil ekstrusi material tersebut ketika menyentuh permukaan shoulder akan dibenamkan kembali, sehingga terlihat mengarah ke bawah. Dua ujung antarmuka dapat dilihat pada bagian melintang tersebut mewakili ujung zona yang dilas, yang disebut hook. 


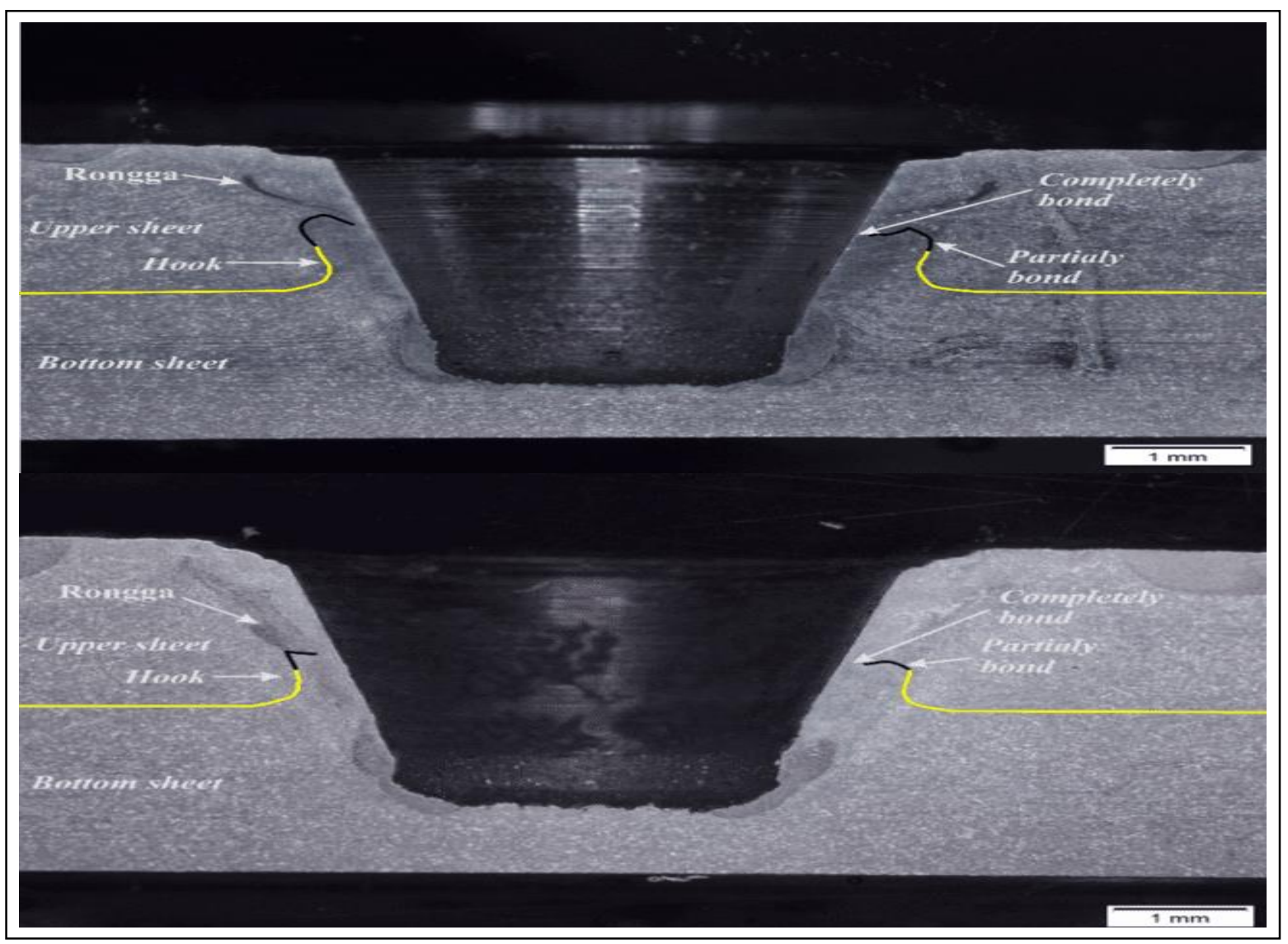

Gambar 4. Tipikal Penampang Sambungan Hasil Pengelasan FSSW Putaran 1500 dan DT 15 s dan Putaran 2250 RPM DT $10 \mathrm{~s}(\mathrm{~A}, \mathrm{~B})$

Hook mengacu pada titik terakhir yang terlihat dari antarmuka antara kedua pelat ke SZ, menjadi cacat geometris yang mempengaruhi kekuatan lasan, karena retakan dapat merambat di sepanjang hook tersebut saat dilakukan pemuatan eksternal (Tran dkk, 2009). Hook diarahkan ke atas untuk mencapai posisi akhir di SZ bagian atas pelat, menunjukkan bentuk seperti bukit kecil. Selama pengelasan, hook terbentuk karena aliran material ke atas dari antarmuka pelat, yang disebabkan oleh penetrasi tool pin. Selanjutnya, film oksida pada antarmuka pelat dipecah menjadi partikel oleh adukan pin tool dan dapat didispersikan ke dalam wilayah las, yang dapat mempengaruhi ikatan metalurgi (Piccini \& Svoboda, 2013).

Meskipun tidak ada cacat yang signifikan, dapat dilihat pada lasan bagian melintang menunjukkan perbedaan pada bentuk hook, ketika pada DT yang lebih lama cenderung lebih tinggi terutama pada kecepatan rotasi $2280 \mathrm{rpm}$. Hal tersebut diakibatkan pada DT yang lebih lama menyiratkan lebih banyak aliran material pada antarmuka sambungan menempatkan posisi hook terakhir jauh dari antarmuka (Piccini \& Svoboda, 2013). Bentuk pin silinder runcing juga akan mengarahkan material lunak serta hook ke atas mendekati rongga hasil estrusi material oleh pin.

\section{Pengamatan Strukturmikro}

Satu spesimen diambil pada penelitian ini di masing-masing variasi pengelasan. Pengamatan dikhususkan pada daerah Base Metal (BM), Heat Affected Zone (HAZ), dan Stir Zone (SZ). 


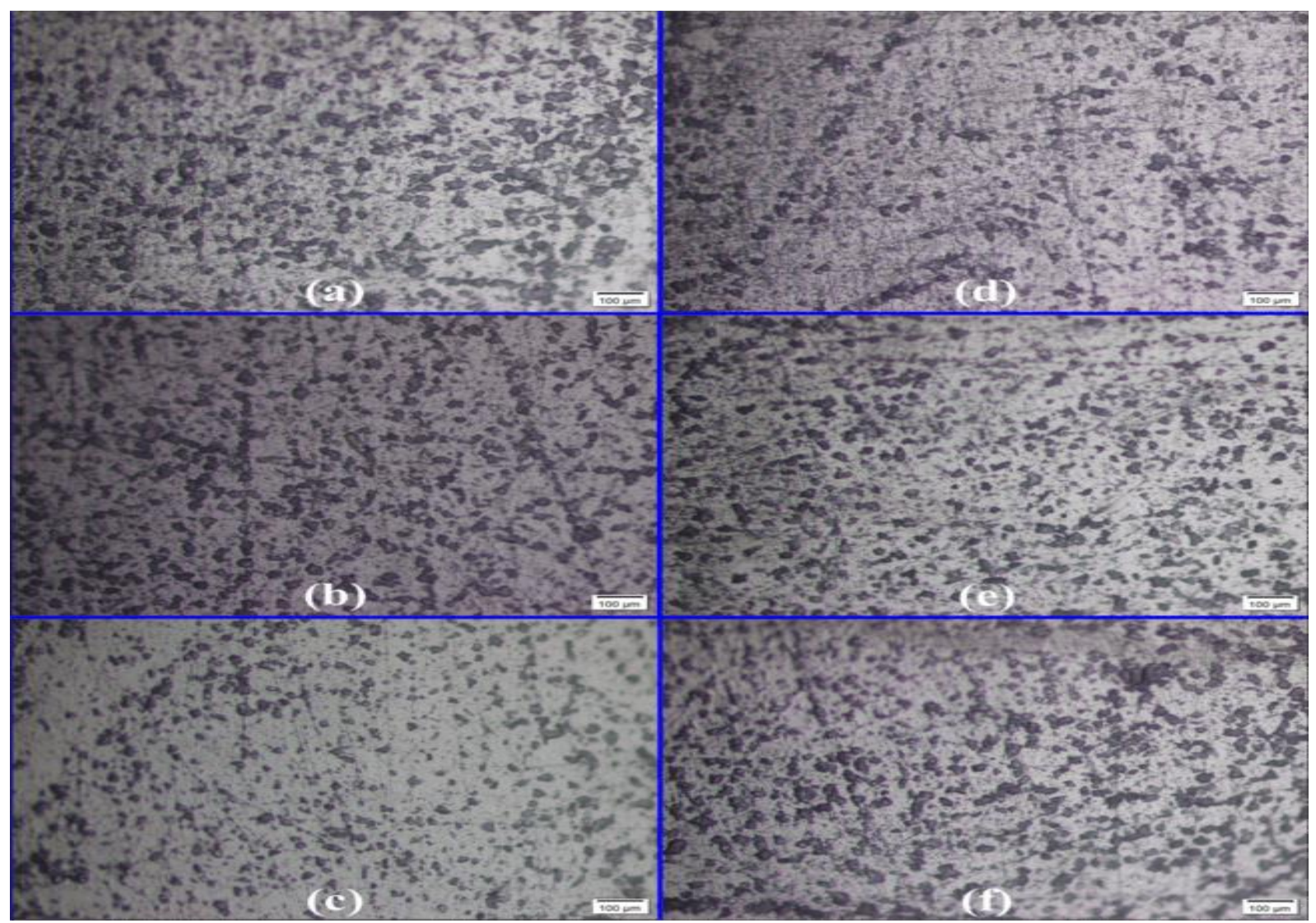

GAMBAR 5. Strukturmikro di daerah HAZ pada Sambungan Hasil Pengelasan FSSW Putaran 1500 dan DT 5, 10 dan 15 s (a,b,c) Putaran 2250 Rpm DT 5, 10 dan 15 s (d,e,f)

Daerah HAZ terjadi perubahan bentuk butir, namun terjadi deformasi plastis di area ini (Gambar 5). Hal tersebut disebabkan pada daerah ini strukturnya hanya dipengaruhi oleh panas dari proses pengelasan. Penelitian Mishra \& Ma (2005) menemukan bahwa hasil uji tarik menunjukkan hasil paling lemah terjadi di HAZ. Namun, bukan berarti setiap kegagalan sambungan karena sifat daerah HAZ tersebut. Badarinarayan, dkk (2009) dalam penelitiannya mengungkapkan bahwa kekuatan sambungan FSSW juga terkait dengan geometri hook. Bentuk butir pada strukturmikro daerah SZ pada DT yang tinggi, ukuran butir terlihat lebih seragam jika dibandingkan dengan DT yang lebih rendah. Hal tersebut mengindikasikan bahwa pada DT yang tinggi menyebabkan pengadukan material oleh tool yang lebih merata.
Pengamatan di semua spesimen terutama di BM, HAZ, dan SZ menunjukkan pada wilayah yang lebih jauh dari pusat lasan yaitu pada BM, strukturmikronya mempunyai bentuk butir berserat memanjang sejajar dengan arah bergulir mengarah ke pipih. Daerah HAZ yang terpengaruh panas, memiliki bentuk butir sedikit oval dan mengecil. Strukturmikro pada SZ yang merupakan wilayah terpengaruh langsung oleh putaran tool dan terdeformasi secara mekanik, mempunyai butir yang lebih halus dan seragam (Gambar 6). Hasil ini membuktikan perubahan bentuk dan ukuran dari strukturmikro saat proses pengelasan berhubungan erat dengan deformasi plastis dan perilaku panas yang terjadi ketika proses pengelasan berlangsung. 


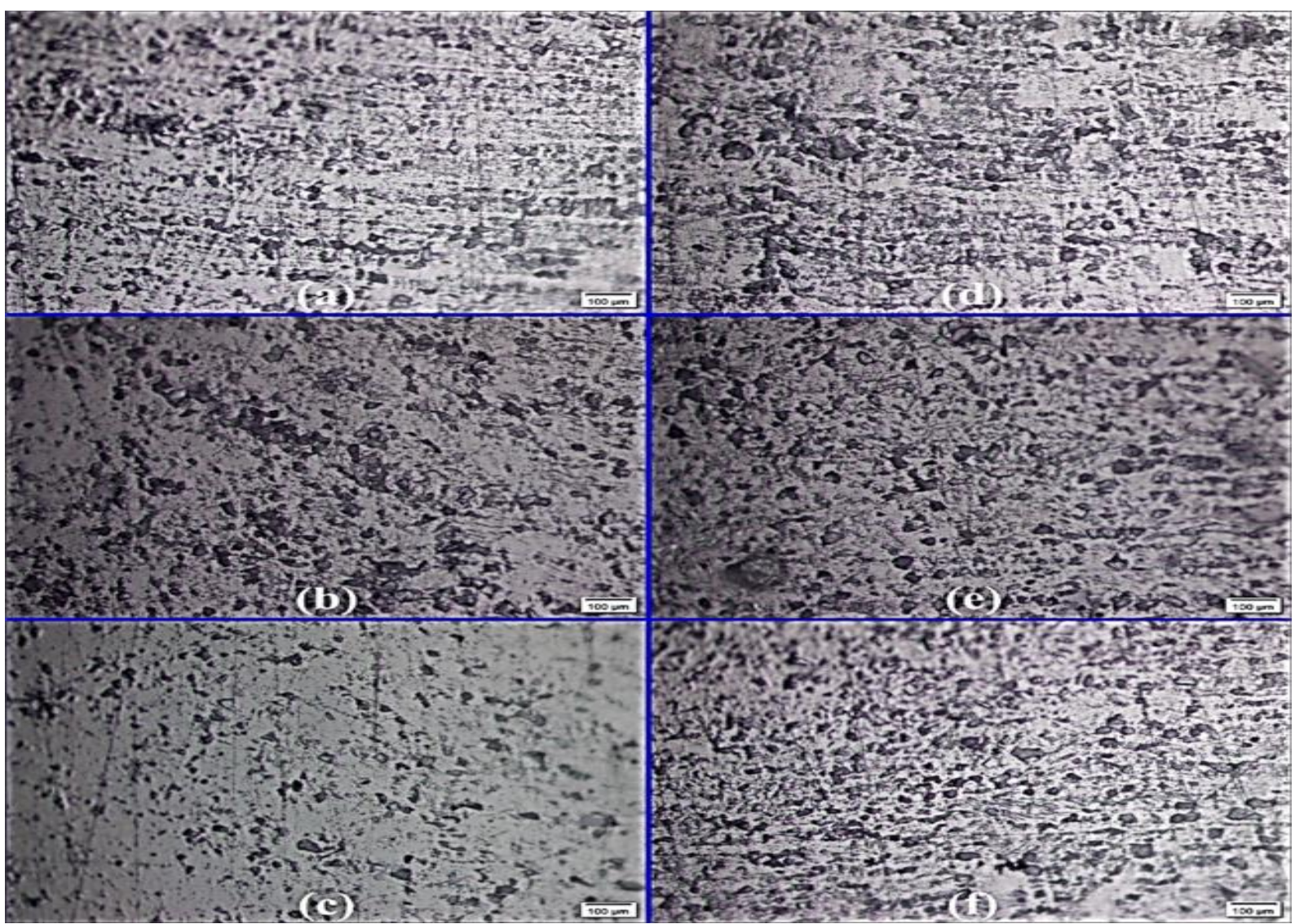

GAMBAR 6. Strukturmikro di daerah Stir Zone pada Sambungan Hasil Pengelasan FSSW Putaran 1500 dan DT 5, 10 dan 15 s (a, b, c) Putaran 2250 Rpm DT 5, 10 dan 15 s (d, e, f)

\section{Pengujian Kekerasan}

Setiap variasi terdapat lima titik pengujian kekerasan yaitu Under Pin (UP), Stir Zone Bottom Sheet (SZBS), Stir Zone Upper Sheet (SZUS), dan Base Metal (BM). Pengujian pada titik SZBS dan SZUS dimaksudkan untuk mengetahui nilai kekerasan di sekitar ujung pin dan area SZ sekitar hook. Skema titik uji dan hasil pengujian kekerasan ditunjukkan oleh Gambar 7. Semua konfigurasi sambungan mengalami kenaikan kekerasan dari logam dasar ke arah lubang kunci sampai di area SZ dan mengalami penurunan di daerah bawah pin (UP), namun tidak lebih rendah dari nilai kekerasan area BM. Efek ini dapat dikaitkan dengan rekristalisasi dinamis yang terjadi di sekitar area lasan dan mengalami perbaikan butir. Sedangkan pada area SZBS (samping dari ujung pin), rekristalisasi dan penyempurnaan butir begitu kuat menghasilkan peningkatan kekerasan. Area hook, terjadi penurunan kekerasan berlanjut ke HAZ dan BM.

Pertumbuhan kekerasan disebabkan oleh modifikasi strukturmikro yang terkait dengan suhu tinggi yang terjadi pada zona lasan. Peningkatan kekerasan dapat dijelaskan oleh dua efek. Pertama, deformasi plastis pada TMAZ meningkatkan kekerasan, apalagi rekristalisasi dinamis dan penyempurnaan butir terjadi di SZ, natural aging dapat terjadi (Mahoney \& Mishra, 2007). Oleh karena itu, uji microhardness terkait erat dengan periode waktu tinggal dari pengelasan. Nilai kekerasan masing-masing spesimen ditunjukkan oleh Gambar 7. 


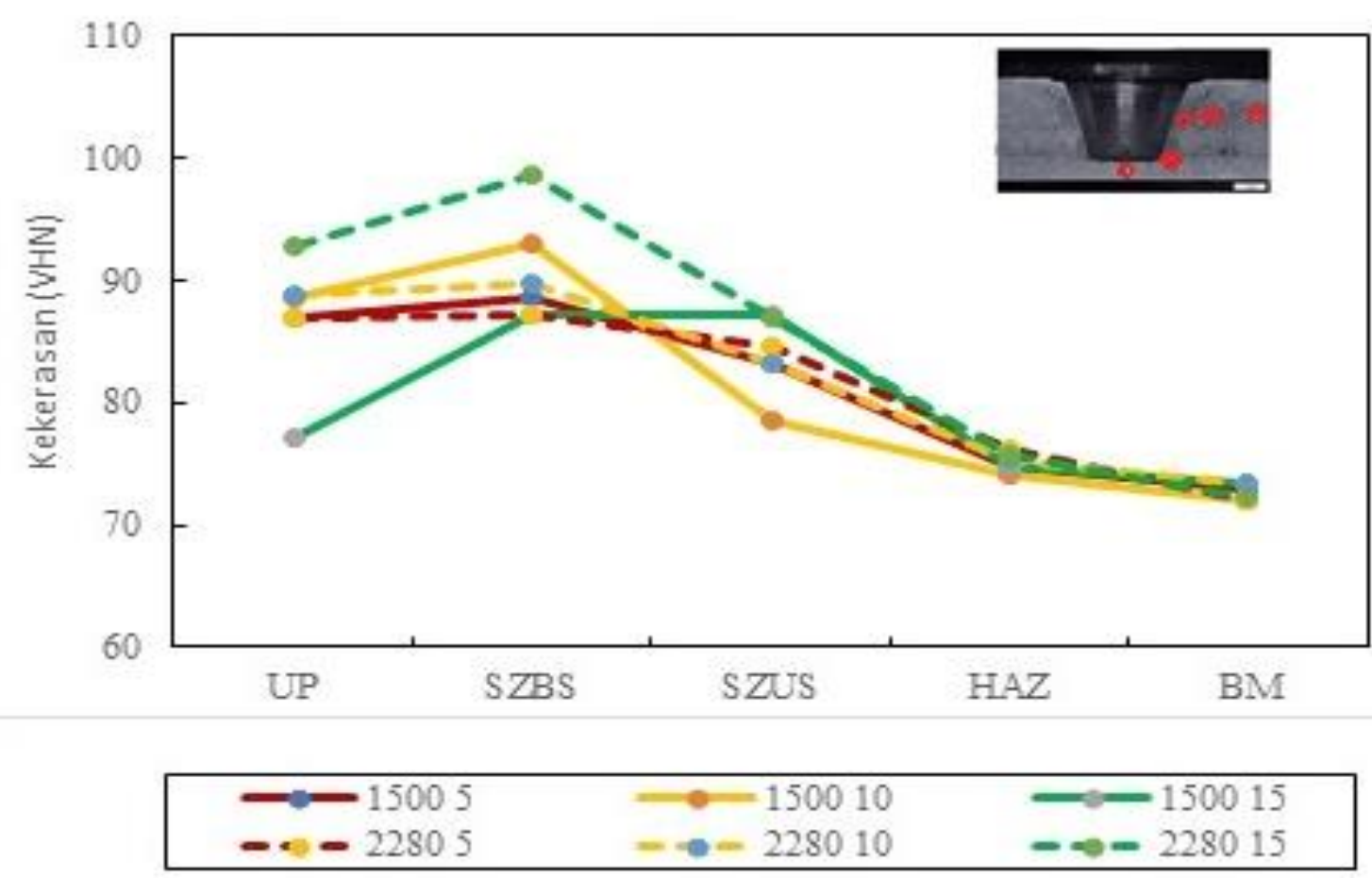

GAMbAR 7. Nilai Kekerasan pada Masing-Masing Zone Sambungan Hasil Pengelasan FSSW Putaran 1500 dan DT 5, 10 dan 15 s Putaran 2250 Rpm DT 5, 10 dan $15 \mathrm{~s}$

\section{Pengujian Tarik}

Hasil dari pengujian tarik diperoleh kekuatan tertinggi terjadi pada kecepatan rotasi $2280 \mathrm{rpm}$ DT 15 s dengan nilai 3105,44 $\mathrm{N}$ dan kekuatan terendah 2543,19 N pada kecepatan rotasi 1500 rpm DT 10 s. Sedangkan untuk standar deviasi tertinggi yaitu 421,37 pada kecepatan rotasi tool $1500 \mathrm{rpm} 10 \mathrm{~s}$, hal ini berarti sebaran data pada variasi tersebut mempunyai nilai yang tidak rata atau selisih jauh antar masing-masing nilainya. Standar deviasi yang rendah terjadi di kecepatan rotasi $2280 \mathrm{rpm}$ DT $10 \mathrm{~s}$ yaitu 88,2 yang berarti sebaran data pada variasi ini relatif lebih merata dan dengan selisih yang tak terlalu jauh, dibandingkan dengan variasi lain. Data hasil pengujian tarik ditunjukkan oleh Gambar 8.

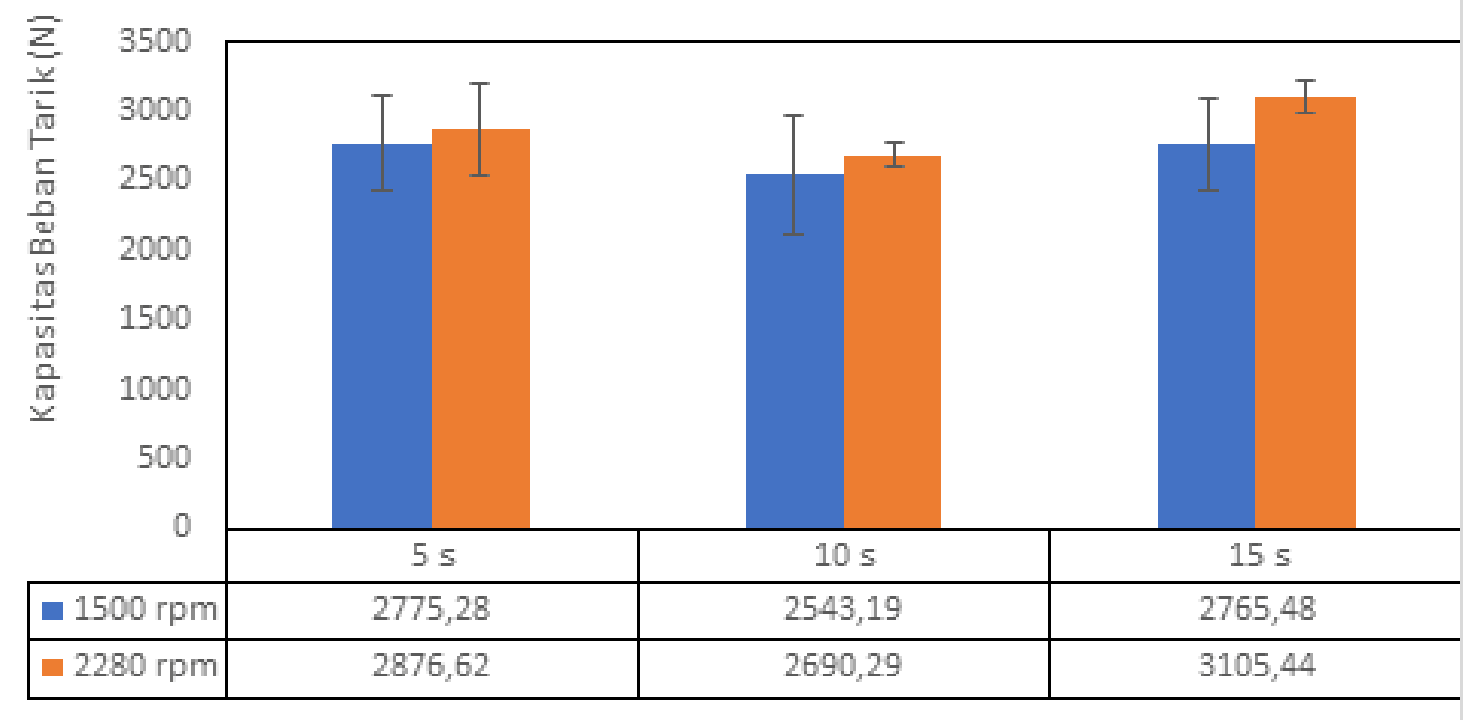

Gambar 8. Hubungan Kapasitas Beban Tarik Geser Terhadap Dwell-Time pada Putaran 1500 \& 2280 Rpm 
Kekuatan terendah 2543,19 N pada kecepatan rotasi $1500 \mathrm{rpm}$ DT $10 \mathrm{~s}$ dapat dihubungkan dengan foto makro spesimen $1500 \mathrm{rpm}$ DT 10 s. Hasil foto makro dapat dianalisa, bahwa hook yang dihasilkan mengarah ke atas dengan bentuk bukit kecil mendekati rongga yang lebih besar jika dibandingkan dengan parameter lain. Bentuk hook yang demikian akan mengarahkan rambatan retakan menuju daerah rongga yang akhirnya bahan uji patah akibat beban dari mesin uji tarik. Kekuatan tertinggi terjadi pada kecepatan rotasi $2280 \mathrm{rpm}$ DT $15 \mathrm{~s}$ dengan nilai 3105,44 N. Variasi ini rongga terlihat terdispersikan akibat adukan material yang lebih banyak karena DT yang lebih lama. Bentuk hook yang dihasilkan tidak jauh berbeda tetapi pada variasi ini lebih tinggi menjauhi antarmuka pelat. Hasil kekuatan uji tarik jika dihubungkan dengan hasil pengujian kekerasan juga berbanding lurus terutama pada bagian SZUS (daerah hook). Hal ini mengindikasikan bahwa properti mekanik dari sambungan FSSW pada aluminium terutama dipengaruhi oleh kekerasan.

Gambar 9 menyajikan mode kegagalan hasil FSSW dengan kecepatan putar pahat dan dwelltime yang berbeda dari sambungan paduan Aluminium 5083. Jenis mode kegagalan yang dapat diamati setelah pengujian tarik pada semua spesimen yaitu nugget pull out. Penelitian Sekhar, dkk (2017) menemukan dua jenis mode kegagalan yaitu nugget pull out dan partially curved interfacial, pada mode kegagalan nugget pull out menunjukkan beban fraktur geser yang lebih kuat dibandingkan dengan kegagalan mode partially curved interfacial.

Kecepatan putar tool berpengaruh signifikan terhadap kekuatan tarik sambungan sementara variasi dwell-time tidak terlalu berpengaruh signifikan. Hal tersebut dibuktikan oleh beban kegagalan tarik dari sambungan mengalami penurunan pada DT $10 \mathrm{~s}$, nilai kekerasan pada variasi ini di kedua kecepatan putar tool juga memiliki nilai paling rendah, terutama di bagian sekitar hook. Nilai beban kegagalan tarik meningkat pada DT $15 \mathrm{~s}$ di semua kecepatan rotasi tool baik $1500 \mathrm{rpm}$ maupun $2280 \mathrm{rpm}$. Hal ini mungkin karena masukan panas yang optimal dan selanjutnya diikuti oleh aliran material yang memadai.

Hasil penelitian ini juga hampir sama dengan hasil penelitian yang dilakukan oleh Zhang, dkk (2011) dan Baskoro dkk (2019) melaporkan bahwa kekuatan sambungan terutama ditentukan oleh kecepatan rotasi sementara itu tidak dipengaruhi secara signifikan oleh waktu tunggu. Sedangkan Lin, dkk (2012) melaporkan fenomena yang berbeda, hasil eksperimen mereka menunjukkan bahwa kecepatan putaran dan waktu diam merupakan faktor dominan terhadap kuat tarik geser. Kekuatan spesimen meningkat dengan bertambahnya waktu tunggu, yang terkait dengan pertumbuhan butir. 


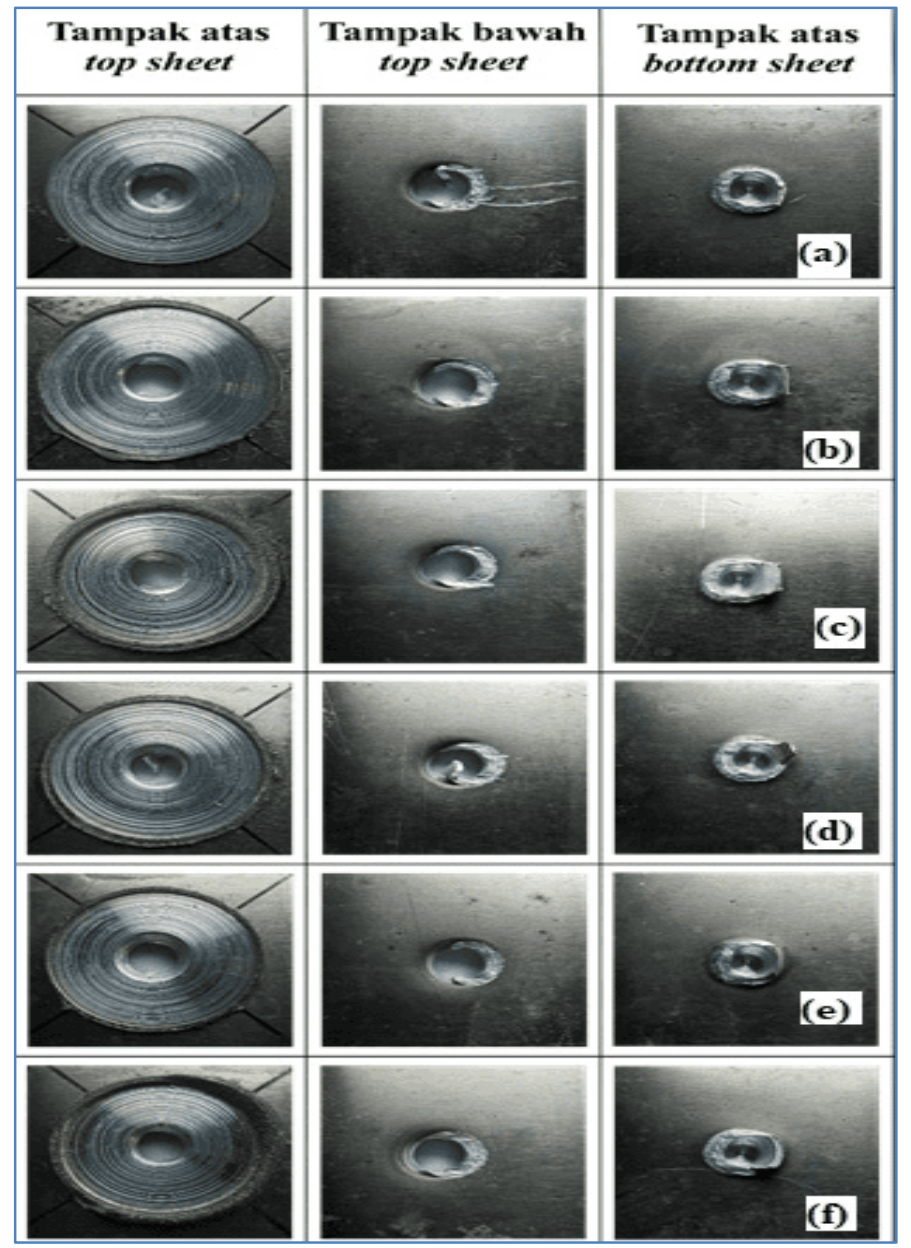

GAMbar 9. Mode Kegagalan Hasil FSSW pada Putaran 1500 DT 5, 10, 15 s (a, b, c) dan Putaran 2250 Rpm DT 5, 10 $15 \mathrm{~s}(\mathrm{~d}, \mathrm{e}, \mathrm{f})$

\section{KESIMPULAN}

Kecepatan rotasi tool berpengaruh cukup signifikan pada temperatur proses pengelasan. Sebagian besar generasi panas terjadi pada antarmuka shoulder dan benda kerja. Pengelasan dengan variasi kecepatan rotasi $2280 \mathrm{rpm}$ dan dwell-time 15 s menghasilkan temperatur proses yang paling tinggi di kedua termokopel $\left(433,18^{\circ} \mathrm{C}\right.$ dan $\left.352,54^{\circ} \mathrm{C}\right)$.

Variasi dengan dwell-time yang lebih lama menghasilkan konfigurasi hook lebih tinggi menjauhi antar muka pelat dan rongga lebih didispersikan. Pengamatan mikro diperoleh bahwa dwell-time yang lebih lama menghasilkan butiran yang lebih halus dan seragam.
Nilai kekerasan berhubungan erat dengan hasil pengujian tarik. Nilai kekerasan yang tinggi terutama di daerah SZUP memiliki kapasitas beban tarik geser yang tinggi. Kapasitas beban tarik geser tertinggi diperoleh pada variasi kecepatan rotasi tool $2280 \mathrm{rpm}$ dengan dwelltime 15 s dengan nilai 3105,44 N. Sedangkan untuk nilai kapasitas beban tarik geser terendah terjadi pada variasi $1500 \mathrm{rpm}$ DT $10 \mathrm{~s}$ sebesar $2543,19 \mathrm{~N}$. Jenis mode kegagalan yang terjadi pada semua spesimen yaitu nugget pull out. Hasil pengujian tarik dan kekerasan menunjukkan bahwa kekuatan sambungan terutama ditentukan oleh kecepatan rotasi dan tidak dipengaruhi secara signifikan oleh $d w e l l$ time. 


\section{UCAPAN TERIMA KASIH}

Penulis dapat menuliskan ucapan terima kasih kepada M Aldianto, J. Amrilah, dan A. Rachim yang telah berkontribusi dalam penelitian ini.

\section{DAFTAR PUSTAKA}

Al-khateeb, M. A., \& Takhakh, A. M. (2011). Effect of tool shoulder diameter on the mechanical properties of 1200 aluminum friction stir spot welding. Journal of Engineering, 17(6), 15171523.

Badarinarayan, H., Shi, Y., Li, X., \& Okamoto, K. (2009). Effect of tool geometry on hook formation and static strength of friction stir spot welded aluminum 5754-O sheets. International Journal of Machine Tools and Manufacture, 49(11), 814-823. https://doi.org/10.1016/j.ijmachtools.2 009.06.001

Badarinarayan, H., Yang, Q., \& Zhu, S. (2009). Effect of tool geometry on static strength of friction stir spot-welded aluminum alloy. International Journal of Machine Tools and Manufacture, 49(2), 142-148. https://doi.org/10.1016/j.ijmachtools.2 008.09.004

Baskoro, A., S., Hadisiswojo, S., Kiswanto, G., Winarto, Amat, M.A., Chen, Z.W., (2019), Influence of welding parameter on macrostructural and thermomechanical properties in micro friction stir welded under high speed rotation, The International Journal of Advanced manufacturing Technology, 106 (1),163-175.

Baskoro, A.S., Ritanto, A., Arifardi, M.F., and Rupajati, P. 2020) Influence of Tool diameter and plunge depth on mechanical properties of micro friction stir spot weling materials A1100, IOP Conference Series: Materials Science and Engineering, 727(2020)012008

Bilici, M. K., \& Yükler, A. I. (2012). Influence of tool geometry and process parameters on macrostructure and static strength in friction stir spot welded polyethylene sheets. Materials \&
Design, $\quad 33$ https://doi.org/10.1016/j.matdes.2011. 06.059

Li, G., Zhou, L., Zhou, W., Song, X., \& Huang, Y. (2019). Influence of dwell-time on microstructure evolution and mechanical properties of dissimilar friction stir spot welded aluminumcopper metals. Journal of Materials Research and Technology, 8(3), 26132624.

https://doi.org/10.1016/j.jmrt.2019.02. 015

Lin, Y. C., Liu, J. J., Lin, B. Y., Lin, C. M., \& Tsai, H. L. (2012). Effects of process parameters on strength of $\mathrm{Mg}$ alloy AZ61 friction stir spot welds. Materials \& Design, 35, 350-357. https://doi.org/10.1016/j.matdes.2011. 08.050

Mahoney, M. W., \& Mishra, R. S. (2007). Friction stir welding and processing. ASM international.

Mishra, R. S., \& Ma, Z. Y. (2005). Friction stir welding and processing. Materials Science and Engineering: $R$ : reports, 50(1-2), $1-78$. https://doi.org/10.1016/j.mser.2005.07. 001

Piccini, J. M., \& Svoboda, H. G. (2015). Effect of the tool penetration depth in Friction Stir Spot Welding (FSSW) of dissimilar aluminum alloys. Procedia Materials Science, $\quad 8, \quad 868-877$. https://doi.org/10.1016/j.mspro.2015.0 4.147

Sekhar, S. R., Chittaranjandas, V., Govardhan, D., \& Karthikeyan, R. (2018). Effect of tool rotational speed on friction stir spot welded AA5052-H38 aluminum alloy. Materials Today: Proceedings, 5(2), 5536-5543.

https://doi.org/10.1016/j.matpr.2017.1 2.144

Tran, V. X., Pan, J., \& Pan, T. (2009). Effects of processing time on strengths and failure modes of dissimilar spot friction welds between aluminum 5754-O and 7075-T6 sheets. Journal of Materials Processing Technology, 209(8), 37243739. 
https://doi.org/10.1016/j.jmatprotec.20 08.08.028

Zhang, Z., Yang, X., Zhang, J., Zhou, G., Xu, X., \& Zou, B. (2011). Effect of welding parameters on microstructure and mechanical properties of friction stir spot welded 5052 aluminum alloy. Materials \& Design, 32(8-9), 44614470.

https://doi.org/10.1016/j.matdes.2011. 03.058

PENULIS:

*Aris Widyo Nugroho

Program Studi Teknik Mesin, Fakultas Teknik, Universitas Muhammadiyah Yogyakarta. Jalan Brawijaya, Tamantirto, Kasihan, Bantul

Email: ariswidyo.nugroho@umy.ac.id

Fajar Hari Purnomo

Program Studi Teknik Mesin, Fakultas Teknik, Universitas Muhammadiyah Yogyakarta, Jalan Brawijaya, Tamantirto, Kasihan, Bantul

Email: fajarpurnomoix@gmail.com

Muhammad Budi Nur Rahman

Program Studi Teknik Mesin, Fakultas Teknik, Universitas Muhammadiyah Yogyakarta, Jalan Brawijaya, Tamantirto, Kasihan, Bantul

Email: budinurrahman@umy.ac.id 